\title{
Model GAE-L \& J. Successful Case at JMAS Cuauhtémoc, Chihuahua
}

\section{Modelo GAE-L \& J. Caso exitoso en la JMAS Cuauhtémoc, Chihuahua}

DOI: $10.46932 / \mathrm{sfjdv2n3-004}$

Received in: May 1st, 2021

Accepted in: Jun 30th, 2021

\author{
Dra. Laura Elizabeth Cavazos González \\ TecNM / Instituto Tecnológico de Cd. Cuauhtémoc \\ Ave. Tecnológico s/n Cuauhtémoc, Chihuahua \\ E-mail: lecg2003@hotmail.com \\ M.A. Javier Aguilar Contreras \\ TecNM / Instituto Tecnológico de Cd. Cuauhtémoc \\ Ave. Tecnológico s/n Cuauhtémoc, Chihuahua \\ E-mail: aguilarcjavier@hotmail.com \\ Selena Veleta García \\ Student \\ TecNM / Instituto Tecnológico de Cd. Cuauhtémoc \\ Ave. Tecnológico s/n Cuauhtémoc, Chihuahua \\ E-mail: veleta_s@hotmail.com \\ Elmer Ayala Gómez \\ Student \\ TecNM / Instituto Tecnológico de Cd. Cuauhtémoc \\ Ave. Tecnológico s/n Cuauhtémoc, Chihuahua \\ E-mail: elmer.ayala.g@gmail.com

\section{Paulina Vélez Ledezma} \\ Student \\ Ave. Tecnológico s/n Cuauhtémoc, Chihuahua \\ E-mail: paauveleez_@hotmail.com
}

\begin{abstract}
In today's world, organizations from both the private and government sectors must renew administration models of their various resources, in search of options for their respective management and optimization as a strategy to increase their competitiveness and efficiency.

Under the priority of implementing innovative business management schemes, the GAE. L \& J Model (Lean Administrative Management. Laura y Javier) emerges, the main objective of which is the administrative diagnosis, the respective design of reengineering strategies and the training and evaluation program. Its premise is the lean administration, applying programs reduction of costs in the areas of operation and administration.

It works with a methodology of qualitative and quantitative type. Its general structure is based on three instruments: Observation and review of processes, staff survey and manager interview. The data is analyzed with Excel and IBM SPSS Statistics.

GAE. L\&J has been implemented since October 2016 to date at the JMAS (Municipal Water and Sanitation Board) of Cuauhtémoc, Chihuahua with excellent results: Change of image in facilities,
\end{abstract}


reduction of workforce, redefinition of the organizational structure with its respective job profiles, manuals and procedures. Currently the staff is trained in providing a quality service to the user leadership, noting that the organization has been awarded and named as spearhead in this new administrative approach, following the proposals and recommendations emanated from the Model GAE.L \& J

Keywords: Model, Management, Lean Administration

\section{RESUMEN}

En tiempos actuales, las organizaciones tanto del sector privado como gubernamental, han de renovar los modelos de administración de sus diversos recursos, en la búsqueda de opciones para su respectiva gestión y optimización como estrategia para incrementar su competitividad y eficiencia.

Bajo la prioridad de implantar esquemas innovadores de dirección empresarial, surge el Modelo GAE.L\&J (Gestión Administrativa Esbelta. Laura \& Javier) cuyo objetivo central es el diagnóstico administrativo, el diseño respectivo de estrategias de reingeniería y el programa de capacitación y evaluación. Su premisa medular es la administración esbelta, aplicando programas de reducción de costos en los rubros de operación y administración.

Trabaja con una metodología de tipo cualitativo y cuantitativo. Su estructura general se basa en tres instrumentos: Observación y revisión de los procesos, encuesta al personal (FDA) y entrevista a directivos (ENDI). Los datos se analizan con Excel e IBM SPSS Statistics.

GAE. L\&J se ha implementado desde octubre de 2016 a la fecha en la JMAS (Junta Municipal de Aguas y Saneamiento) de Cuauhtémoc, Chihuahua con excelente resultado: Cambio de imagen en las instalaciones, reducción de la plantilla laboral, redefinición de la estructura organizacional con sus respectivos perfiles de puestos, manuales y procedimientos. Actualmente se capacita al personal en brindar un servicio de calidad al usuario, destacando que dicho organismo ha sido galardonado y denominado como punta de lanza en este nuevo enfoque administrativo, a raíz de las propuestas y recomendaciones emanadas del Modelo GAE.L\&J

Palabras Clave: Modelo, Gestión, Administración esbelta,

\section{INTRODUCTION}

Technological breakthroughs, economics globalization and new business trends, entails a disruptive change on the standard management scheme in which the private sector such as public, have to renew the administration models of its several resources, on the quest of choices in order to manage and optimize as a strategy to increase efficiency and competitiveness.

Change management, requires organization's flexibility and the skills from their executives to foresee and respond assertively through demanding stages. Pascale, quoted by Mora (2017) states that the companies must be "inquiry's engines" if it is conceived as a growth and adaptive opportunity.

Valero (2008) postulates that when introducing changes into companies, have to be done matching criteria, concepts and rules which therefore must be spread in all areas and introducing it gradually.

In light the challenges described and under priority to implement innovational business management frameworks, the model GAE. L\&J (Lean Administrative Management. Laura y Javier) arises, whose main objective is diagnose, reengineering strategies design and training and evaluation 
program. Its main premise is the lean administration, applying costs reduction programs on operating and management entries. Change implies resistance, implementing it requires strength and make out results requires patience.

\section{PROBLEM STATEMENT}

The organizations require to fight costs in order to reach competitivity, not just at manufacturing area, but logistics, marketing and management so as the budgets matches and applies with the guidelines which promotes Banco Interamericano de Desarrollo (BID) through the management for results in development (Garcia,2015).

Current context sets innovative solutions to maximize business resources, working with less in order to achieve more, reducing though design of integral reengineering models waste and improving operations on a total worker's respect to manage an innovational administration.

\subsection{OBJECTIVES}

On the following sections it's described the objectives prom the current studies.

\subsection{GENERAL OBJECTIVE}

Design an administrative management model which optimizes the organism's resources effectively and assertively, reducing costs and improving the operation quality.

\subsubsection{Specific Objectives}

a) Elaborate an instrument to perform the administrative diagnoses.

b) Design a base tool so as to the executive's interviews.

c) Implement the model in order to measure relevance.

\section{MODERN MANAGEMENT AND ORGANIZATIONAL STRUCTURE MODELS}

\subsection{MODERN MANAGEMENT}

Summing up Sarmiento's ideas (2011), it's synthesized that Frederick Taylor and Henry Fayol defined on the beginning of the past century key statements on the new management's stage such as: specialization, authority and responsibility, unity and command tenet, order, equity, initiative and teamwork among others. 
Meza (2014) states that according to Peter Drucker (father of modern administration), managing is "planning, organizing, directing and controlling the resources of an organization for economic or social purposes" and where all the parts of a company should turn around the process.

Modern management, emanated from the oriental philosophies which have based their activities on process management, encloses some terms such as:

1. Benchmarking: Lanfet (2017), quoting Spendolini, defines it as "the continuous and systematic process of evaluating the products, services or processes of organizations that are recognized by representatives of best practices for the purposes of organizational improvement".

2. Empowerment: Meza (2014) referring to Juan Bravo Carrazco, affirms that this term is the "decision to delegate functions to subordinates in order to give them greater participation and involvement in the decision-making of the company and ensure that executives will concentrate on the key business activities."

3. Coaching: According to the National Institute of Entrepreneurs (INADEM) (2017), this concept is defined as "training to find solutions." Its objectives are: "promote greater awareness in interpersonal relationships and skills, emphasize the importance of a generative and not only corrective change in client behaviors and abilities; focus the values and beliefs of the organization to turn their goals into useful realities for him and his workplace."

4. Downsizing: Soto (2011) defends that it is "a restructuring or reorganization of companies through which work systems are improved, organizational and personnel redesign is carried out to maintain competitiveness in the market and social changes " In general, it is a general reduction in processes with a series of strategies for rethinking (retaking, rebuilding), resizing (measuring) and rightsizing (correct measurement. Mora (2011) stipulates that it implies the creation of innovation in new products, new services and new market based on customer needs).

5. E-commerce: To Ramírez (2017) it is "the process by in which two or more parties carry out a business transaction through a computer and an access network" with the aim of generating new, cheaper economic impersonal sales channels, more agile and uninterrupted. 
6. Seven \"S \" of Mckinsey. Meza (2011) clarifies that this famous consultant company proposed the $7 \backslash " S \backslash "$ approach to the corporate structure:

a) Strategy: General plan of action to achieve the objectives according to available resources.

b) Structure: The way in which the areas of a company are defined and assembled including their coordination relationships and ranking.

c) Skills: The distinctive capabilities of the company and that differentiate it from its competitors.

d) Shared values: refers to the mission, vision and values shared by members of an organization.

e) Systems: The processes and procedures required to implement the strategy.

f) Style: Leadership exercised by senior management and line managers primarily.

g) Staff: Employees of the organization who execute the strategy decided by senior management.

7. Outsourcing: Economía simple.net (2016) states that the definition for this term of modern administration is "the hiring of services to third parties by a company in order to develop complementary activities besides its main activity, in other words the service improvement, business specialization and time and stock savings.

8. Competitive advantage: Cavazos (2014) based on Michel Porter (1982) defines it as the superiority achieved over the immediate competitors, being able to be in the product itself or in the marketing mix. This advantage is internal when the company focuses on costs apportionment and is external when it is directed to the market domain.

According to Manene (2012), process-based reengineering is a way of acting against change, based on efficient processes focusing on customer satisfaction, managing cost and waste reduction. He mentions that Michael Hammer and James Champy, through the book 'Reengineering', allowed the mass and rapid diffusion of this concept from 1994. 


\subsection{LEAN MANAGEMENT}

After an exhaustive review of the state of sovereign art on the subject referred, the search is synthesized in two definitions which completes the concept to the purpose of this research.

Loza (2015) defines Lean Management as "the set of useful tools that do not add value to the product, service or processes, improving operations, based in respect to the worker".

To González (2007), Lean Manufacturing, it is "a set of "Tools" that help to identify and eliminate or waste combination (change), to improvement in quality and reduction in time and production costs." An example of this is continuous improvement (kaizen), troubleshooting methods such as Five whys and they are error-proof systems (poka yokes) or the "production flow" (mura) through the system and not towards waste reduction or kanban (label system to identify products) or heijunka (Leveling production to demand).

The concept arises in the production areas but due to its great success, it has extended to the rest of the operating processes in the organizations, searching an improvement that positions them in a greater competitiveness.

\subsection{INSTRUMENTS TO MAKE A DIAGNOSIS OF ORGANIZATIONAL STRUCTURE}

There are so many instruments or questionnaires to make a diagnosis in organizational positions, such as policies or management styles. The following describes those that were considered most consistent to the purpose of this research.

\subsubsection{Alejandro ávila (2002)}

The created model is called "Cargo Analysis Questionnaire Format" and divides it into 9 categories: Identification, job summary, description of responsibilities, physical and intellectual requirements, environmental conditions, risks, knowledge required by the position, experience and training. It is very complete and its variables are multiple and correlate perfectly. Onto the ongoing study it was considered very extensive and difficult to code.

\subsubsection{Job description format (middle and top commands) (2010)}

This format is based on the Technical Guide for the Preparation of Procedural Manuals What is implemented in Guerrero's government State, 5 sections consisted: General data, objective of the position, controls, internal and external relations of the position and requirements. Although it is easier to code than the previous one because it establishes tables for each variable, it considers many aspects very subjective such as loyalty, growth or effort and this becomes difficult to measure. 


\subsubsection{Jorge everardo aguilar morales (2010)}

The questionnaire to elaborate the analysis of positions under this format establishes 8 parameters: job description and specification, experience, work conditions, risks, physical and socioeconomic aspects and psychological requirements. It is considered very broad and tends itself to very ambiguous answers since all questions are open.

\subsubsection{Traditional job analysis interview model}

This model is integrated by: identification of the position, organization chart, summary and functions of the position, tasks, methods and tools, required knowledge, experience, necessary performance times, levels of autonomy, responsibility and consequences of the decisions taken and work environment. It is very complete but focused on management levels.

\subsubsection{Seizing a Theoretical Perspective}

Interrelating to the concepts of lean administration and diagnostic approaches to organizational structure is designed the GAE Model L\&J (Lean Administrative Management. Laura y Javier). This proposes through the elaboration of own instruments to carry out the administrative diagnosis, the respective design of reengineering strategies and the training and evaluation program in an organization. Its core premise is lean administration, applying cost reduction programs in the operation and administration areas.

Management Diagnostic Form (FDA) (2016). This questionnaire was designed according to the objectives of the present study and after analyzing more than ten different models. It consists of general information, location of the position, general objective of the position, description of main activities, internal and external relations of the position, decision making, responsibilities, supervision, work environment, use of tools, requirements of the position, training, strategic planning aspects knowledge level.

Executives' Interview Guide (ENDI) (2016) contemplates elements such as the profile of the position and who performs it, real and suitable functions, and number of personnel in charge, skills, professional experience and also as in the position, strategic planning and changes impact.

\section{APPLIED METHODOLOGY TO DEVELOP THE GAE MODEL. L\&J}


The methodological design is qualitative and quantitative, cross-sectional, and is structured for public or private sectors that request its application.

\subsection{DESIGN}

The qualitative studies to LeCompte (1995) quoted by Herrera (2008), are "works which extract descriptions from observations who take the form of interviews, narratives, field notes, audio recordings, videos, records or photographs." They focus according to the author, on the environment of events and their inquiry is in natural or taken contexts as they are. Quantitative studies according to Cimacyt (Center for Mathematical Research Applied to Science and Technology, Quantitative Studies) (2015) quoted by Cavazos (2015) "are those research that allow us to examine the data in numerical form with the help of statistical and sampling tools", and use surveys, reports or business documents, for example brand tracking. The "hard data" of the specific groups are obtained in order to get statistical results, and through an objective, inferential, deductive and generalizable measurement with solid and repeatable data.

Under the void prevailing fulfilling authors expectations at the time of conducting business consulting methodology, in 2016 the idea of generating an administrative model for this purpose arose. The state of the art was analyzed; those approaches and models that showed similarity to the objective of the model were selected. It was decided to divide it into three phases: administrative diagnosis preview observing processes, the corresponding reengineering design of strategies and the training and evaluation program. Excel and the IBM SPSS Statistics program are used for data analysis.

\section{RESULTS}

The result obtained was the development of the GAE Model. L\&J whose structure is as follows:

On Phase 1 Administrative Diagnostic, the state art analysis was resorted and consequently two instruments arise:

Management Diagnostic Form (FDA) in 2016 which is described in section 3.4 (Annex 1) and the Executives' Interview Guide (ENDI) (Annex 2) also described in section 3.4, which are applied preview observation at the processes of the requesting company. In the second phase, Process Reengineering is recommended; the proper fixing strategies are designed. In the third one, named Training and Evaluation Program, the courses to implement several improvements are outlined.

The GAE Model. L\&J was implemented at JMAS from Cuauhtémoc city, Chihuahua through the Instituto Tecnológico de Cd. Cuauhtémoc, obtaining the following results:

The work is cross-sectional due it consists of three phases. The first called Administrative DIAGNOSTIC (See Table 1). The second is identified as Process Reengineering based on the 
development, for example, of OPERATION MANUALS (See Table 2). The third phase is identified as a Training and Evaluation Program (See Table 3).

In phase 1, implemented in October 2016 to February 2017 (See Table 1), two instruments were used in a workforce compound by 174 people, arranged in the matrix, sewage plant and branch: The first FAP (Annex 1) was applied to all the Institution's staff, except the executive team. It consists of 18 questions and deems the characteristics and position profile, who currently covers it, work environment, training, among other aspects described in section 3.4.

The second was the ENDI (Annex 2). Six semi-structured interviews were conducted with the management team. In addition, was discussed in an open interview with the JMAS CEO on three occasions. Information on laws regarding water issues, books and articles were collected via internet. The study was complemented with observation at different times of the day.

Table 1 Phase 1 Administrative Diagnostic

\begin{tabular}{|l|l|l|}
\hline ACTIVITY & PERFORM & DATE \\
\hline Project Application and first negotiations & $\begin{array}{l}\text { Principal office } \\
\text { ITCC/JMAS }\end{array}$ & October 2016 \\
\hline Teamwork structure & & November 2016 \\
\hline Work Schedule presentation & & November 2016 \\
\hline Probing & Teachers & December 2016 \\
\hline JMAS executives team meetings & Teachers & December 2016 \\
\hline Current situation position analysis & Teachers & December 2016 \\
\hline Organization chart analysis & Teachers & December 2016 \\
\hline Surveys making & Teachers & December 2016 \\
\hline Executives Interviews & Teachers & December 2016 \\
\hline Personnel surveys & Students & $\begin{array}{l}\text { December } \\
\text { and January 2016 }\end{array}$ \\
\hline Data coding analysis & Teachers & January 2017 \\
\hline $\begin{array}{l}\text { Analysis results presentation and Reengineering } \\
\text { Strategies proposals }\end{array}$ & Teachers & February 2017 \\
\hline
\end{tabular}

In Phase 2, dated February to June (See Table 2), the proposed organizational structure is developed as well as the sundry manuals which contain the Reengineering strategies.

Table 2 Phase 2 Organization manual

\begin{tabular}{|l|l|l|}
\hline Activity & PERFORM & DEADLINE \\
\hline Organizational Structure & Teachers & June 2017 \\
\hline Operation Manual & Students & August 2017 \\
\hline Procedure Manual & Teachers and students & October 2017 \\
\hline
\end{tabular}


Table 3 Phase 3 Training and Evaluation Program

\begin{tabular}{|l|l|l|}
\hline Course & PERFORM & DATES \\
\hline $\begin{array}{l}\text { Customer Service } \\
\text { Management }\end{array}$ & Teachers & September 11-15th 2017 \\
\hline High Performance Motivation & Teachers & October 16-20th 2017 \\
\hline Executive Skills & Teachers & November 6-10th 2017 \\
\hline
\end{tabular}

\section{CONCLUSIONS}

Resistances to change, the uncertainty of implementing new processes are inherent in the new paradigms. Facing them and even promoting them are avant-garde dyes, because as Driemel (2015) mentions, it has benefits as stakeholders (all parties involved in the organization) and a workforce more committed and motivated to work for the organization's objectives as well as generating managers who manage a sustainable change with a free information flow.

The GAE Model. L\&J was applied with an absolute success at Junta Municipal de Agua y Saneamiento de Cd. Cuauhtémoc Chihuahua now that some of the most outstanding achievements recorded since its implementation was:

1. Reduction of the workforce.

2. New organizational structure according to the real organization needs, ceasing unnecessary positions and functions.

3. Making organization manuals and procedures related from the previous issue.

4. The administrative, operational and executive personnel are being trained to participate actively in the stated changes and also be in tune with the objectives of the JMAS Cuauhtémoc, Chihuahua.

5. Change in facilities, providing a renewed corporate image.

6. The agency has been cataloged as a spearhead at a state level, not only in the state but in other national latitudes.

7. The Institution was awarded for the achievements obtained, in part for the measures established based on the study carried out.

The road has only begun and the task is hard going. Work continues and perfecting the GAE Model. L\&J to implement it in organizations that challenge competition based on a slender administration.

Change implies resistance, implanting requires courage and observing results demands patience. 


\section{REFERENCES}

1. Aguilar Morales, J. E. (2010) Formato y Cuestionario para Elaborar el Análisis de Puestos, Network de Psicología Organizacional, Asociación Oaxaqueña de Psicología A.C., México

2. Ávila Alejandro (2002) Formato de Cuestionario de Análisis de Cargo, mayo 2002, http://www.gestiopolis.com/formato-de-cuestionario-de-analisis-de-cargos/ consultada 12 de diciembre del 2016

3. Cavazos L. (2015) Comunicación para el desarrollo (CPD): Gestión Estratégica para que se Escuche la Voz del Pueblo Rarámuri, XXX Congreso Latinoamericano de Sociología, ALAS, Costa Rica

4. Cavazos L. (2014) Tesis Doctoral Estrategias de Comunicación para el Desarrollo. Posibles Aplicaciones en el Sector Quesero Menonita de Cuauhtémoc, Chihuahua, Universidad de Sevilla, España

5. Driemel A (2015) Gestión del Cambio, http://www.driemelcoaching.com/es/soluciones/consultoria/desarrollo- organizacional/gestion-delcambio/ 2013-2017 consultada 15 agosto 2017

6. Economía Simple(2016) Definición de Outsourcing, https://www.economiasimple.net/glosario/outsourcing consulta 25 octubre del 2016

7. Formato Modelo Entrevista Tradicional para Análisis de Puestos http://contenidos.campuslearning.es/CONTENIDOS/371/curso/pdf/FICHA-PDDRH-U3-A5- D1PDF\%20N\%C2\%BA\%201.pdf, (sin especificación de año), consultada 11 diciembre del 2016

8. García R. (2015) Gestión para Resultados en el Desarrollo BID, IDBx, an online learning initiative of Inter-American Development Bank (IDB) through edX

9. González F. (2007) manufactura Esbelta (Lean Manufacturing), Principales Herramientas Beachmold Mexico S. de R.L. de C.V. Vol. 1, Núm. 2, pag 86 francisco170879@yahoo.com.mx

10. Guía Técnica para la Elaboración de Manuales de Procedimientos (2010), Formato de Descripción de Puestos (Mandos Medios y Superiores) Dirección General de Gestión Administrativa, gobierno del Estado de Guerrero

11. Herrera J., (2008) La Investigación Cualitativa, https://juanherrera.files.wordpress.com/2008/05/investigacion-cualitativa.pdf consultado 15 de enero 2017

12. INADEM (2017) Blog del Emprendedor Capacitación Diferencia entre Coaching y Capacitación, 10 marzo, 2017 https://www.inadem.gob.mx/diferencia-entre-coaching-y- capacitacion/ consulta 11 enero del 2017

13. Lanfet C. (2017) Primeros Conceptos de la Administración Moderna, 3 de Marzo de 2017 http://www.pqs.pe/actualidad/noticias/primeros-conceptos-sobre-administracion-moderna consulta 22 febrero del 2017

14. Loza J. (2015) Administración Esbelta Editor Facultad de Contaduría y Administración, Maestría en Administración http://ri.uaemex.mx/handle/20.500.11799/34224 consulta 14 marzo del 2017 
15. Manane L. (2012), Reingeniería de Procesos Empresariales y su Gestión en en Conocimientos, Gestión Del Personal, Habilidades Directivas y, Mejora Continua 23 enero 2012 http://www.luismiguelmanene.com/2012/01/23/reingenieria-de-procesos-empresariales-y-su- gestion-2/ consulta 13 febrero 2017

16. Meza E. (2014) Primeros Conceptos sobre Administración Moderna, Instituto de Formación Bancaria (IFB). Diciembre 2014 http://www.pqs.pe/actualidad/noticias/primeros-conceptos- sobreadministracion-moderna consulta 13 septiembre del 2017

17. Mora C. (2011) Resizing, Rightsizing y Downsizing en las Organizaciones, 1 octubre 2011 http://managersmagazine.com/index.php/2011/10/resizing-rightsizing-y-downsizing-en-lasorganizaciones/ consulta 15 diciembre del 2016

18. Mora C (2017) Artículo La Relevancia e Importancia de la Gestión del Cambio, Marzo 14, 2017 https://entorno-empresarial.com/la-relevancia-e-importancia-de-la-gestion-del-cambio/ consulta 20 julio 2017

19. Ramírez J. (2017) El ABC del E-commerce 10 marzo 2017 https://www.entrepreneur.com/article/268503, consulta 7 de abril del 2017

20. Sarmiento I (2011) Evolución del Pensamiento Administrativo, Licenciatura en Administración, Universidad Autónoma del Estado de Hidalgo-Huejutla julio.diciembre del 2011,ttps://www.uaeh.edu.mx/docencia/P_Presentaciones/huejutla/administracion/temas/evo lucion_del_pensamiento_administrativo.pdf consulta 25 julio del 2017

21. Soto B. (2011) Qué es el Downsizing en los Recursos Humanos, 3 marzo 2011 https://www.gestion.org/recursos-humanos/29481/que-es-el-downsizing-en-los-recursos-humanos/ consulta 7 de enero del 2017

22. Valero A.(2011) Artículo Factores Clave para Adaptarse y administrar el Cambio, 29 de agosto del 2011 http://www.logisticamx.enfasis.com/notas/20238-factores-clave-adaptarse-y-administrar-elcambio, consulta 12 agosto del 2017 


\section{ANNEX}

\section{ANNEX 1}

JOB ANALYSIS FORM

\section{General Information:}

\section{Elaboration Date}

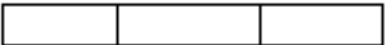

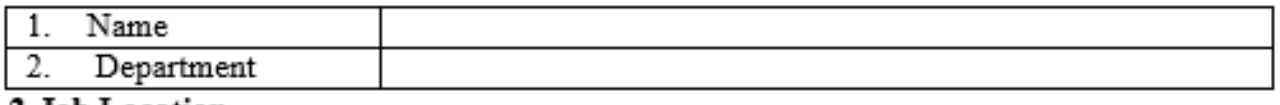

\section{Job Location.}

\begin{tabular}{|l|l|}
\hline 1. Job Description & \multicolumn{2}{|l|}{} \\
\hline 2. Work position & Own ( ) Internship ( ) Fixed-Term ( ) \\
\hline 3. Contract Type & None ( ) Defined ( ) Undefined ( ) \\
\hline 4. Salary & \\
\hline 5. Schedule & \\
\hline 6. Num. Personnel in charge: & \\
\hline 7. Jobs under in Charge: & \\
\hline 8. Line Manager Superior: & \\
\hline 9. Besides Answers to: & \\
\hline 10. Located in chart & \\
\hline
\end{tabular}

3. Job General Objective: (Define briefly in what consist your job)

4. Describe the activities done at your job, (In general terms, describe the duties you perform, please list in descending order of importance).

\begin{tabular}{|l|l|}
\hline Daily: & Aplied work hours \\
\hline & \\
\hline Monthly or Others: & \\
\hline & \\
\hline Occasionally: & \\
\hline & \\
\hline Other Duties: & \\
& \\
\hline
\end{tabular}


5. Relations: Does your job require contact with customers and suppliers of the department, other departments, other companies or organizations? Please define the obligations your work requires.

Intern Relations:

\begin{tabular}{|l|l|l|l|}
\hline Who & Area & Frequency & Reason \\
\hline & & & \\
\hline & & & \\
\hline
\end{tabular}

\section{External Relations:}

\begin{tabular}{|l|l|l|l|}
\hline Who & Company & Frequency & Reason \\
\hline & & & \\
\hline & & & \\
\hline
\end{tabular}

6.Decision Making: Please explain the decisions you make to fulfill your job duties.

a) What would be the likely outcome of your misjudgments or your "provider" (internal or external) that does not respond in a timely manner

7. Records responsibility: List the records and files you must prepare or keep updated, explain, in general terms, to whom each report is addressed to, and its content.

\begin{tabular}{|l|l|l|}
\hline Report & Addressed to & Content \\
\hline & & \\
\hline & & \\
\hline
\end{tabular}

8. Supervision frequency: How often should you speak with your supervisor or third parties to make decisions, or to determine the action's due course to follow?

() Daily () Weekly () Monthly () Annually

9. Briefly describe, as regards your work, how your boss

Organize

Assigns

Your work is evaluated by your immediate boss

10. Working conditions: Describe the conditions in which you work: Indoors, outdoors, with air conditioning etc., be sure to mention all pleasant working conditions, unpleasant or out of the ordinary.

11. 11. Work environment: Mark your personal satisfaction level on the position you hold:

( ) Excellent ( ) Very good ( ) Good ( ) Regular ( ) Bad

12. Equipment used to perform your job: or mention work tools you need, if that's the case.

\begin{tabular}{|l|l|}
\hline Equipment & Time Used \\
\hline & \\
\hline
\end{tabular}

13. Special requirements: (List the licenses, permits, certifications, etc. which you require to perform the corresponding duties of your position)

14. Job requirements: (Write down the minimum requirements that you consider necessary to successfully complete your work.)

(a) Schooling

Minimum Scholarship: Elementary () Middle School () High School ()

College:

\section{(b) Experience}

Job:

Years:

Professional Knowledge: 
(c) Special Training:

\begin{tabular}{|l|l|l|}
\hline Type & Time & Received by \\
\hline \multicolumn{2}{|l|}{} & \\
\hline \multicolumn{2}{|l|}{} \\
\hline (d) Job Required Skills & & \\
\hline Techniques or management of equipment & Human \\
\hline & & \\
\hline
\end{tabular}

ANEXO 2

ASPECTS TO CONSIDER IN THE SEMI-STRUCTURED INTERVIEW WITH CHIEFS JMAS CUAUHTÉMOC CHIHUAHUA

JOB:

Date

Name

\begin{tabular}{|l|l|}
\hline PROFILE & \\
\hline Real & \\
\hline Adequate & \\
\hline FUNCTIONS & \\
\hline Real & \\
\hline Adequate & \\
\hline N. PERSONNEL IN CHARGE & \\
\hline SKILLS & \\
\hline WORK EXPERIENCE & \\
\hline $\begin{array}{l}\text { JOB } \\
\text { EXPERIENCE }\end{array}$ & \\
\hline IRREGULARITIES FOUND & \\
\hline $\begin{array}{l}\text { PLANNING TO C, L } \\
\text { DEADLINE }\end{array}$ & \\
\hline CHANGE IMPACT & \\
\hline OBSERVATIONS & \\
\hline
\end{tabular}

